\title{
Development of a mechanism for making administrative decisions on the use of leasing
}

\author{
Guzaliya Klychova, ${ }^{1, *}$, Alsou Zakirova ${ }^{1}$, Angelina Dyatlova ${ }^{2}$, Gamlet Ostaev ${ }^{3}$, Marat \\ Faizrakhmanov ${ }^{4}$, and Nadezhda Pimenova ${ }^{3}$ \\ ${ }^{1}$ Kazan State Agrarian University, Karl Marx, 65, Kazan, 420015, Russia \\ ${ }^{2}$ Moscow University of the Ministry of Internal Affairs of the Russian Federation named after V. J. \\ Kikot, Academic Volgin, 12, Moscow, 117997, Russia \\ ${ }^{3}$ Izhevsk State Agricultural Academy, Studencheskaya, 11, Izhevsk, 426069, Russia \\ ${ }^{4}$ Ministry of Finance of the Republic of Tatarstan, Pushkin, 37, Kazan, 420015, Russia
}

\begin{abstract}
In modern agriculture with its technical needs, it is almost impossible without effective management measures and borrowing capital. Stable development of agriculture, including crop production, certainly depends on technical equipment of agricultural enterprises. The use of financial instruments and management mechanisms is an opportunity for agricultural producers to improve their potential, including the improvement and maintenance of agricultural equipment at an appropriate level, since the activity involves in the performance of a large volume of mechanized work for the production of strategically important products. The aim of the article is to justify the theoretical provisions and to develop the mechanism of management decision making on the use of leasing in the activity of agricultural organizations. The objectives of the research: to analyze the material and technical support of agricultural organizations of the Republic of Tatarstan; based on the use of sociological methods of research to propose an algorithm for determining the variant of the form of financing capital investment, which is based on the choice of alternative options for the reproduction of machine and tractor fleet. The proposed mechanism for making managerial decisions on the use of leasing in the activities of agricultural organizations contributes to improving the efficiency of the production system and provides renewal and formation of technical and technological potential of the industry.
\end{abstract}

\section{Introduction}

The future of any agricultural enterprise depends on making managerial decisions, using mechanisms and financial instruments $[1,2,3]$. Making competent, timely management decisions should be done by management accounting specialists.

Leasing refers to a unique financial instrument, and at the same time it is a mechanism that integrates the properties of leasing, credit and financial investments, forming new forms of business activity $[4.5,6]$.

"Corresponding author: zakirovaar@mail.ru 
The use of leasing in the sphere of agro-industrial complex assumes forms of state regulation, for example, credit (leasing payments by seasons) and tax benefits $[7,8,9,10]$. The adopted managerial decisions on application of mechanisms and instruments of financing (leasing) allow agricultural producers to get access to purchase of expensive machinery and equipment, it is accompanied by specialized service, due to this the time for maintenance and service is reduced, which is especially important during seasonal work $[11,12,13]$.

Currently, leasing, as a financing mechanism and instrument, has taken a very strong position in the world economy, but in each state the level of its development is different [14]. It mainly depends on the state of the country's economy as a whole and the interest of the state itself in stimulating leasing relations. In particular, stimulation can be carried out by means of clear legal regulation of leasing relations [15].

In developed countries leasing is one of the important levers influencing the investment activity, bringing a huge effect not only to the direct participants of leasing operations, but to the economy as a whole. The success of leasing activities as a mechanism and instrument of financing in any industry largely depends on the correct understanding of its contents and specific features, their adequate reflection in methodological recommendations and practical solutions [16]. An important feature of leasing operations as a mechanism and instrument of financing is that the subject of leasing transferred into temporary possession and use of the lessee, is the property of the lessor during the whole term of the leasing agreement. The right of possession and use of the subject of the lease is transferred to the lessee in full at the moment of its receipt unless otherwise stipulated by the lease agreement. At the same time, when using this mechanism and financing instrument, the risk of accidental destruction or accidental damage of the leased property shall also pass to it, unless otherwise is provided for by the financial lease agreement.

\section{Materials and Methods}

The modern stage of agro-industrial complex development is characterized by conducting production activities based on the introduction of new generation technology and modern agro-technologies $[17,18]$. In this connection in the agro-industrial complex of Russia there should be formed an effective innovation system, based on technological development, technical renovation, conjuncture of material and human resources market, financial and economic mechanism, the use of modern approaches to management of material and technical support $[19,20]$. The basis of organizational and economic mechanism of agricultural production is the state support for stimulation of technical re-equipment, modernization of machine and technological base of agro-industrial complex, development of material and technical resources market, improvement of technical equipment and technological potential, price parity of agriculture and processing industries, credit system and leasing mechanism, taxation system $[21,22]$.

The material and technical base of agriculture has a number of peculiarities that should be taken into account in the process of development of material and technical support of the agrarian sector of production. Successful technical modernization of agrarian production is to create certain conditions for effective technical re-equipment of agricultural sector based on state support. Agricultural enterprises should form an optimal machinery and technology park in terms of quantity and quality.

Currently, there are several ways of receiving fixed assets: their acquisition for a fee under the contract of sale, construction (manufacturing), the founders' contribution to the authorized capital, receipt under the contract of gift and other income. The cost of agricultural products, which is one of the key performance indicators of agricultural producers, depends on the choice of the optimal variant of their acquisition. 
The system of logistics accumulates a significant amount of information about material, labor and financial resources, their needs, supply in the market, the size of supply, their price, suppliers, etc $[23,24,25]$. In this connection, it is necessary to form an information support system when managing the logistics system [26, 27]. Analyzing the existing logistics strategies and the existing software for their implementation, we can conclude that it is possible to automate the processes of logistics management.

The leading role in logistics of agricultural producers is assigned to land resources - the main means of production [28]. Land resources differ in terms of fertility and, consequently, different costs for agricultural production are required.

The main part of the country's territory is made up of agricultural lands (Tables 1,2).

Table 1. Area of agricultural land by categories of farms(as of 1 January 2019; thousand hectares)

\begin{tabular}{|c|c|c|c|c|c|c|c|c|}
\hline Agricultural land & $\begin{array}{c}\text { Farms of all } \\
\text { categories }\end{array}$ & $\begin{array}{c}\text { Agricultural } \\
\text { organiza- } \\
\text { tions }\end{array}$ & $\begin{array}{c}\text { Peasant (farm) } \\
\text { households and } \\
\text { individual } \\
\text { entrepreneurs }\end{array}$ & $\begin{array}{c}\text { Households of } \\
\text { population }\end{array} \mid$ & $\begin{array}{c}\text { Personal } \\
\text { subsidiary } \\
\text { and other } \\
\text { individual } \\
\text { farms of } \\
\text { citizens }\end{array}$ & $\begin{array}{c}\text { Non-profit } \\
\text { associations } \\
\text { of citizens }\end{array}$ & $\begin{array}{c}\text { Citizens, } \\
\text { Land } \\
\text { owners }\end{array}$ & $\begin{array}{l}\text { Citizens, } \\
\text { land share } \\
\text { owners }\end{array}$ \\
\hline Total & 4538.1 & 2599.9 & 356.5 & 1518.0 & 112.9 & 49.5 & 183.4 & 1172.2 \\
\hline Arable land & 3403.1 & 1749.4 & 306,1 & 1347.6 & 101.6 & 11.8 & 164.1 & 1070.1 \\
\hline Hayfields & 131.5 & 96.4 & 10.8 & 24.3 & 3.8 & 0.9 & 3,6 & 16.0 \\
\hline $\begin{array}{l}\text { Pastures(Grass } \\
\text { Land) }\end{array}$ & 898.6 & 750.0 & 39.5 & 109.1 & 1.2 & 6.8 & 15.4 & 85.7 \\
\hline $\begin{array}{l}\text { Long-term } \\
\text { plantations }\end{array}$ & 40.5 & 3.6 & 0.1 & 36.8 & 6.3 & 30.0 & 0.3 & 0.2 \\
\hline Deposit & 0,7 & 0,5 & - & 0,2 & - & - & - & 0,2 \\
\hline $\begin{array}{l}\text { Average area of } \\
\text { agricultural land } \\
\text { per organization } \\
\text { (farm), ha }\end{array}$ & $\mathrm{x}$ & 868 & 97 & $\mathrm{x}$ & 0.17 & 0.13 & 9.6 & 4.8 \\
\hline
\end{tabular}

As it can be seen from Table 1, the largest specific weight in the overall structure of agricultural land in farms of all categories is arable land $-75 \%$. The share of arable land in agricultural organizations is $67.3 \%$, in peasant (farm) holdings - $85.9 \%$, in households $88.8 \%$. The sown area of agricultural crops in the period from 2014 to 2018 fluctuates. Thus, from 2014 to 2016 there is an increase by 4.6\%, and in 2018 compared to 2017 there was a decrease by $3 \%$. In the structure of sown areas (see Table 2), the largest share in 2018 is occupied by cereals and fodder crops, 50 and 35.7 percent respectively.

The level of land use has a significant impact on the availability and efficiency of other means of production in agriculture (Table 3 ).

Analyzing the availability of agricultural organizations with agricultural machinery, we see that per 1000 hectares of sowing (planting) of the corresponding crops the number of grain harvesters fluctuates and is at an average level of 2.2 pcs. Significant fluctuations are observed in the availability of potato harvesters.

Crop production is a modern high-tech industry that requires a rational system of fertilization (Table 4).

The proportion of the area fertilized with mineral fertilizers in the whole area under crops fluctuates between 2014 and 2018. Moreover, we can observe a $4.5 \%$ decrease in 2018 compared to 2017 . The amount of fertilizers applied in 2018 , as converted into $100 \%$ nutritious fertilizers, decreased by $20.4 \%$ compared to 2017 . 
Table 2. Crop area (in all categories; thousands of hectares)

\begin{tabular}{|c|c|c|c|c|c|}
\hline Cultivated area & 2014 & 2015 & 2016 & 2017 & 2018 \\
\hline Total & 2924.6 & 3024.3 & 3060.8 & 3058.7 & 2966.5 \\
\hline Cereal crops & 1572.3 & 1595.1 & 1591.7 & 1534.0 & 1484.0 \\
\hline Winter crops: & 496.1 & 491.6 & 515.9 & 477.5 & 464.7 \\
\hline Wheat & 244.2 & 300.5 & 332.4 & 326.6 & 346.1 \\
\hline Ryes & 239.2 & 182.4 & 180.5 & 149.2 & 115.5 \\
\hline Triticale & 12.7 & 8.7 & 3.0 & 1.6 & 3.0 \\
\hline Spring grain crops: & 1076.2 & 1103.5 & 1075.8 & 1056.5 & 1019.3 \\
\hline Wheat & 488.9 & 493.9 & 454.7 & 410.3 & 373.8 \\
\hline Corn for grain & 28.3 & 35.2 & 94.9 & 56.2 & 53.7 \\
\hline Barley & 413.9 & 410.7 & 372.1 & 387.9 & 413.2 \\
\hline Oats & 73.0 & 73.0 & 61.8 & 64.8 & 71.0 \\
\hline Millet & 1.8 & 1.4 & 1.3 & 0.6 & 0.5 \\
\hline Buckwheat & 10.7 & 16.6 & 26.3 & 54.0 & 33.3 \\
\hline Cereals are everything & 59.6 & 72.5 & 64.6 & 82.5 & 73,7 \\
\hline Peas & 54.4 & 62.0 & 54.4 & 70.2 & 63.8 \\
\hline Industrial crops: & 218.2 & 217.1 & 311.0 & 282.8 & 360.1 \\
\hline Flax & 1.0 & 1.1 & 1.1 & 1.1 & 1.1 \\
\hline Sugar beet & 48.4 & 57.7 & 63.2 & 74.0 & 64.3 \\
\hline Oilseeds cultures & 168,7 & 158,2 & 246.6 & 207.6 & 293.8 \\
\hline Sunflower & 81,0 & 55,1 & 110.2 & 131.4 & 124.1 \\
\hline \begin{tabular}{|l} 
Spring Rapeseed (kolza) \\
\end{tabular} & 79,6 & 86,3 & 100.0 & 58.8 & 119.6 \\
\hline Potatoes and vegetable crops: & 71.1 & 72.0 & 67.5 & 65.7 & 64.2 \\
\hline Potatoes & 60.7 & 62.0 & 58.0 & 55.7 & 54.2 \\
\hline $\begin{array}{l}\text { Vegetables (including } \\
\text { seedlings) }\end{array}$ & 10.4 & 10.0 & 9.5 & 10.0 & 10.0 \\
\hline $\begin{array}{l}\text { Feed crops: } \\
\end{array}$ & 1063.0 & 1140.1 & 1090.6 & 1176.2 & 1058.2 \\
\hline $\begin{array}{l}\text { Root crops, including beets } \\
\text { feed sugar }\end{array}$ & 2.5 & 2.3 & 2.4 & 2.0 & 2.1 \\
\hline Feed corn & 188.1 & 185.0 & 141.8 & 184.3 & 147.8 \\
\hline Annual herbs & 266.0 & 319.3 & 262.8 & 295.0 & 230.2 \\
\hline Perennial herbs & 536.4 & 568.8 & 621.7 & 620.5 & 611.7 \\
\hline $\begin{array}{l}\text { Net vapor area (including } \\
\text { black) }\end{array}$ & 307.7 & 230.3 & 214.2 & 262.2 & 274.3 \\
\hline
\end{tabular}

Table 3. Availability of agricultural organizations with agricultural machinery (end of year)

\begin{tabular}{|l|r|r|r|r|r|}
\hline \multicolumn{1}{|c|}{ Agricultural machinery } & 2014 & 2015 & 2016 & 2017 & 2018 \\
\hline $\begin{array}{l}\text { It is necessary to harvesters for 1000 hectares of crops } \\
\text { (planting) of the corresponding }\end{array}$ & & & & & \\
\hline Grain harvest & 2.2 & 2.2 & 2.2 & 2.3 & 2.4 \\
\hline Potato harvest & 19.1 & 13.7 & 16.4 & 19.1 & 16.6 \\
\hline Flax harvesting & 4.7 & 6.0 & 4.6 & 4.5 & 4.9 \\
\hline Beet harvesters (without & 2.5 & 2.0 & 2.0 & 2.0 & 2.2 \\
\hline $\begin{array}{l}\text { It is necessary to sow (plant) the corresponding crops on one } \\
\text { combine, ha: }\end{array}$ & & & & & \\
\hline Grain harvest & 462 & 445 & 454 & 428 & 423 \\
\hline Corn-harvester & 366 & 257 & 710 & 391 & 411 \\
\hline Potato harvest & 52 & 73 & 61 & 52 & 60 \\
\hline Flax harvest & 215 & 167 & 220 & 224 & 204 \\
\hline Beet harvesting machine (without Harvesting) & 393 & 508 & 500 & 499 & 450 \\
\hline It takes 100 tractors, pcs..: & & & & & \\
\hline Ploughs & 23 & 21 & 22 & 22 & 24 \\
\hline Cultivators & 41 & 41 & 43 & 43 & 43 \\
\hline Seeders & 35 & 34 & 34 & 34 & 35 \\
\hline Rake & 6 & 7 & 7 & 7 & 7 \\
\hline Mowers & 12 & 12 & 12 & 12 & 13 \\
\hline
\end{tabular}


In recent years, agricultural producers in the Republic of Tatarstan have been actively working to modernize and increase their material and technical base. For example, they are actively working on the capital construction of a number of production and non-production facilities, implementing programmes to develop a number of industries, introducing new varieties and technologies.

Table 4. Application of mineral fertilizers in agricultural organizations

\begin{tabular}{|c|c|c|c|c|c|}
\hline Indicators & 2014 & 2015 & 2016 & 2017 & 2018 \\
\hline \multicolumn{6}{|l|}{$\begin{array}{l}\text { Introduced mineral fertilizers } \\
\text { (in terms of } 100 \% \text { nutrients): }\end{array}$} \\
\hline just, like, a thousand quintals & 1072.7 & 976.4 & 1029.4 & 1435.3 & 1143.0 \\
\hline per 1 hectare, $\mathrm{kg}$ & 47 & 42 & 44 & 65 & 55 \\
\hline \multicolumn{6}{|l|}{ including under: } \\
\hline corn-free crops & 54 & 47 & 51 & 75 & 63 \\
\hline sugar beet & 283 & 217 & 239 & 315 & 324 \\
\hline Flax-long & 51 & - & 38 & 29 & 33 \\
\hline sunflower & 37 & 16 & 29 & 45 & 43 \\
\hline vegetable and melon crops & 176 & 248 & 422 & 345 & 299 \\
\hline potatoes & 259 & 235 & 353 & 360 & 397 \\
\hline fodder crops & 24 & 23 & 20 & 31 & 25 \\
\hline $\begin{array}{l}\text { Specific weight of fertilized area in the whole sown } \\
\text { area, percent }\end{array}$ & 73.8 & 71.2 & 71.4 & 79.4 & 75.8 \\
\hline
\end{tabular}

Thus, analyzing the material and technical support of agricultural organizations in the Republic of Tatarstan, one can note the great potential for its development, which implies further reproduction of material and technical resources, contributing to a significant increase in the efficiency of agricultural sectors. In order to ensure food security of the region, it is necessary to accelerate the growth rate of production volumes based on increasing its competitiveness.

\section{Results}

In the course of the research for the purposes of making managerial decisions, we conducted a survey of experts (acceptance of the sociological method of research, it involves active participation of the researcher in data collection). In our case, the survey was conducted by phone and during communication when visiting the office of the company. The experts were competent representatives (managers and chief specialists) of the leading agro-industrial enterprises. The survey sheet is presented in Table 5.

Table 5. Questionnaire sheet (sociological method)

\begin{tabular}{|c|l|}
\hline $\begin{array}{c}\text { No of } \\
\text { Questions }\end{array}$ & \multicolumn{1}{c|}{ Contents of the questions } \\
\hline 1 & How strong is your company's need to purchase agricultural machinery? \\
\hline 2 & How much machinery have you purchased (for the crop sector) in the last year? \\
\hline 3 & What forms of financing do you use when purchasing agricultural machinery? \\
\hline 4 & Which source of financing do you consider more promising? \\
\hline 5 & What can you offer for improving leasing programs? \\
\hline 6 & Are there any plans to further purchase machinery in leasing? \\
\hline 7 & If you do not use leasing, what prevents it? \\
\hline
\end{tabular}

The survey results are presented below. To the question: "How much is your enterprise's need to purchase agricultural machinery?", the ranking of opinions is presented in Table 6. The table shows that most agricultural enterprises have an average need for machinery. This is the opinion of $62.5 \%$ of respondents. 
Table 6. Ranking of respondents' opinions about the need of enterprises in agricultural machinery

\begin{tabular}{|l|c|c|}
\hline \multicolumn{1}{|c|}{ Respondent's opinion } & $\begin{array}{c}\text { Have this opinion in \% of } \\
\text { respondents }\end{array}$ & $\begin{array}{c}\text { Rank of this } \\
\text { opinion }\end{array}$ \\
\hline Average need for technology & 62.5 & 1 \\
\hline High need for technology & 31.2 & 2 \\
\hline No need & 6.3 & 3 \\
\hline
\end{tabular}

To the second question of the questionnaire: "What quantity of machinery did you purchase (for the crop industry) during the last year?", the results of your opinions are reflected in Table 7. During the survey it was found that in addition to tractors and combines, companies purchase a significant number of trailed and attached units such as: presses, rakes, balers and others.

Table 7. Ranking of expert opinions according to the number of equipment purchased

\begin{tabular}{|l|c|c|}
\hline $\begin{array}{c}\text { Number of equipment } \\
\text { purchased }\end{array}$ & $\begin{array}{c}\text { Expressing this opinion } \\
\text { in \% of respondents }\end{array}$ & Response rank \\
\hline over 15 units & 53.1 & 1 \\
\hline 6 to 15 units & 37.5 & 2 \\
\hline 1 to 6 units & 9.4 & 3 \\
\hline
\end{tabular}

When asked the following question: "What forms of financing do you use when purchasing agricultural machinery?", many respondents said that they use several forms of financing at once. Together with own funds they use bank credits and take equipment in leasing, but still the majority of respondents put bank credits in the first place $-84.4 \%$, leasing as a form of financing is used only by $34.4 \%$ of respondents. The results are presented in Table 8.

Table 8. Ranking of respondents' opinions depending on the form of financing the purchase of agricultural machinery

\begin{tabular}{|l|c|c|}
\hline \multicolumn{1}{|c|}{ Form of financing } & $\begin{array}{c}\text { Have this opinion in \% of } \\
\text { respondents }\end{array}$ & Response rank \\
\hline Bank loans & 84.4 & 1 \\
\hline Own funds & 68.8 & 2 \\
\hline Leasing & 34.4 & 3 \\
\hline
\end{tabular}

To question 4: "Which source of funding do you consider more promising?", the ranking of opinions is presented in Table 9. The table shows that the first and second places are occupied by own funds and bank loans $-43.8 \%$ and $40.6 \%$ respectively, the rest $15.6 \%$ are occupied by leasing.

It is connected with the fact that at purchase on own funds the enterprise does not pay interest for the credit/leasing, and at purchase on credit the majority of enterprises receive subsidies from the regional budget.

Table 9. Ranking of respondents' answers to the question of a promising source of financing

\begin{tabular}{|l|c|c|}
\hline \multicolumn{1}{|c|}{ Form of financing } & $\begin{array}{c}\text { Have this opinion in \% of } \\
\text { respondents }\end{array}$ & Response rank \\
\hline Own funds & 43.8 & 1 \\
\hline Bank loans & 40.6 & 2 \\
\hline Leasing & 15.6 & 3 \\
\hline
\end{tabular}

When asked: "What can you offer for improving leasing programs?", the experts found it difficult to answer.

To the question: "Is it planned to purchase equipment in leasing?", 56,2\% of respondents answered that it is difficult to answer, only $25 \%$ confidently answered that in the future they will purchase equipment in leasing. The results of opinions distribution are given in the table 10 .

To the last question of the questionnaire: "If you do not use leasing, what prevents it?", 
the respondents were not provided with any options.

The main barrier to use leasing, according to the interviewed experts, is lack of sufficient state support in the form of subsidies and subsidies from federal and regional budgets.

Table 10. Distribution of opinions of the interrogated on further acquisition of equipment in leasing

\begin{tabular}{|l|c|c|}
\hline Respondent's response & $\begin{array}{c}\text { Have this opinion in \% of } \\
\text { respondents }\end{array}$ & Response rank \\
\hline Hard to answer & 56.2 & 1 \\
\hline Yes & 25.0 & 2 \\
\hline No & 18.8 & 3 \\
\hline
\end{tabular}

When making managerial decisions, it is necessary to take into account that another negative factor hindering the use of leasing is the lack of clear information on the advantages of leasing in comparison with other options for financing capital investments and the difficulty of evaluating the advantages of numerous options of leasing programs faced by agricultural entrepreneurs. Therefore, in order to make managerial decisions and improve leasing, an attempt has been made to develop methodological approaches to the choice of investment financing options and the choice of a leasing program.

As a result of the conducted research for management purposes, we came to the conclusion that in order to make managerial decisions, representatives of enterprises need recommendations to help them choose the option of financing investments. If we are going to dwell on such variant of the mechanism and instrument of financing as leasing, there is a need for explanations in terms of choosing a leasing program.

For the purposes of making managerial decisions, we propose the following algorithm for choosing the variant of the form of capital investment financing, which is based on the choice of alternative variants of reproduction of the machine and tractor park (Figure 1).

In the first stage, it is necessary to decide on the option of technical equipment for the crop production industry (Table 11). It is necessary to decide: to organize the repair of equipment, or to involve third parties to perform the work, or to purchase new or used equipment.

In the second stage, the calculation of costs associated with the implementation of technical equipment is carried out.

In the third stage, the choice of the form of financing, technical equipment of the industry is made.

Table 11. Algorithm for choosing the form of financing capital investments

\begin{tabular}{|l|l|}
\hline $\begin{array}{l}\text { Selecting technical } \\
\text { equipment option }\end{array}$ & $\begin{array}{l}\text { - repair, restoration of equipment; } \\
\text { - purchase of used equipment; } \\
\text { - acquisition of new equipment; } \\
\text { - involvement of third-party services. }\end{array}$ \\
\hline $\begin{array}{l}\text { Calculation of technical } \\
\text { equipment costs }\end{array}$ & $\begin{array}{l}\text { - the cost of repair work; } \\
\text { - price of a new car at the time of purchase; } \\
\text { - the cost of acquiring equipment at the expense of the loan; } \\
\text { - the cost of acquiring leasing equipment; } \\
\text { - cost of services of third parties. }\end{array}$ \\
\hline Choice of financing form & $\begin{array}{l}\text { - equity; } \\
\text { - borrowed capital; }\end{array}$ \\
\hline
\end{tabular}

The advantage of such mechanism and instrument of financing, as leasing in the field of agro-industrial complex is that it does not exclude, and even implies other forms of state regulation, such as tax and credit privileges. With the help of leasing, it is also possible to 
overcome to some extent the monopoly of agricultural machinery producers through the use of other sources of obtaining equipment: import, restoration of worn-out parts, multiple use by different consumers, etc. Besides, leasing expands access to expensive machines, reduces the time of economic use, and is accompanied by branded service.

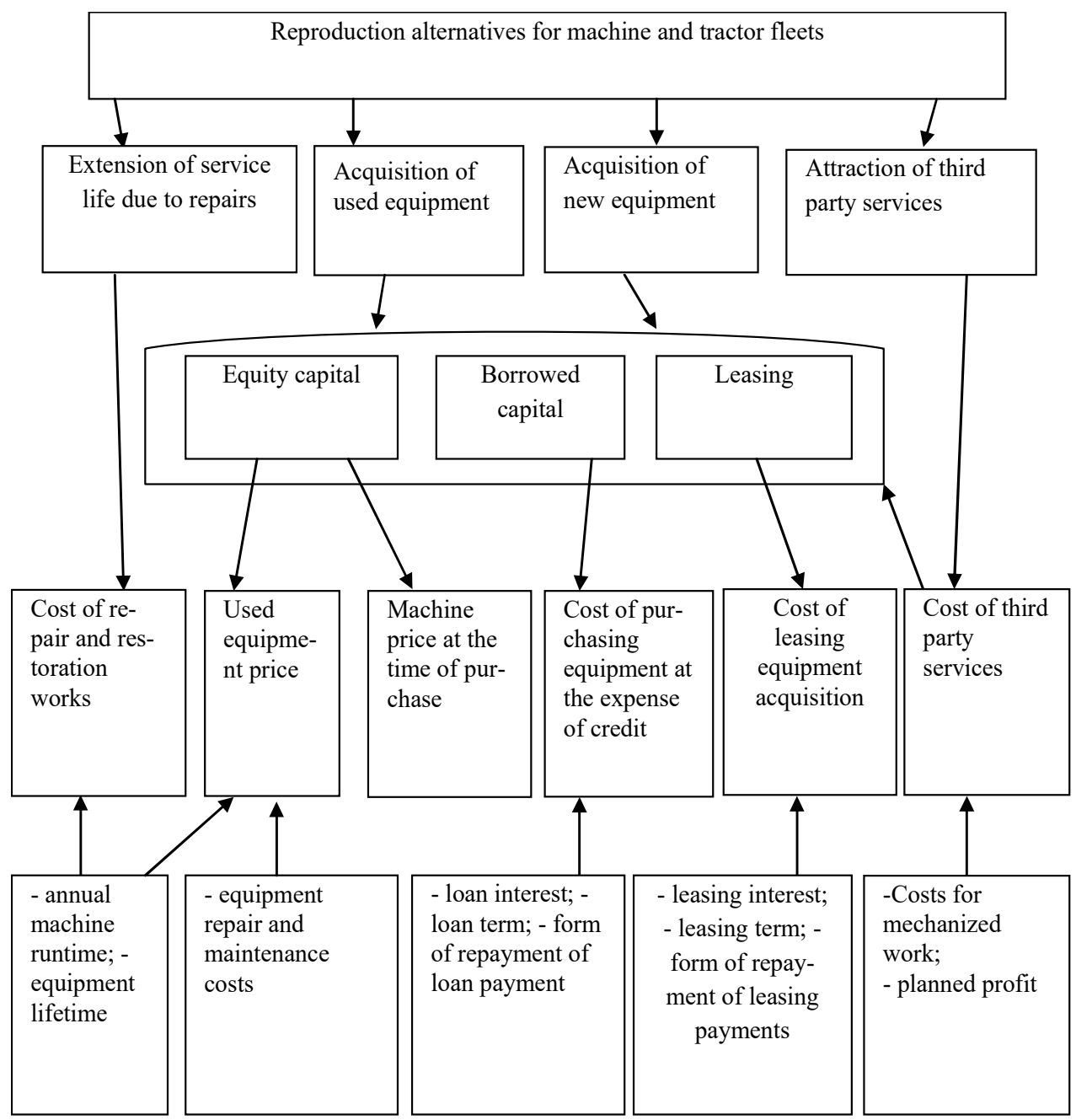

Fig. 1. Alternative options for reproduction of machine and tractor fleet

An essential condition for the development of agroleasing is the possibility and need to pay for leasing payments in kind, i.e. agricultural products.

Agro-leasing - sale of machinery and equipment to consumers with deferred payment is as if a further development and a kind of technical means rental, at the same time it is similar to the rental of tangible assets. In general, this system involves: factories producing machinery, leasing companies, users - agricultural producers, investors, intermediaries providing consulting, service, training and other services.

Thus, for agricultural producers, such a financing mechanism and instrument as leasing simultaneously solves two significant problems - acquisition of machinery and its financing. As a result, the formation and renewal of the technical and technological potential of the sector is ensured, as well as the necessary development of the agricultural sector. 


\section{Discussion}

Leasing specialists divide the leasing process into three main stages: preparatory, organizational (investment) and operational. Each stage has its own peculiarities, which should be taken into account when choosing a leasing program. When choosing a leasing program, it is necessary to compare the elements of leasing programs for each of these stages.

At the first preparatory stage, an agricultural enterprise interested in the technical equipment of agriculture should develop a business plan for the sector. The goals set in the business plan will influence the choice of investment objects - technical means. Thus, within the framework of resource-saving technologies and surface treatment, a complex of technical means, corresponding designs and adjustment systems are needed. Taking into account the said above, the first step of the algorithm we offer is the choice of those leasing programs that will provide the acquisition of technical means corresponding to the selected technology and the developed business plan.

At the second and third stages of the leasing process it is necessary to compare leasing programs taking into account the criterion of minimizing the cost of technical equipment of the project. Thus it is necessary to consider not only obvious expenses (prices, interest on the invested capital), but also the implicit expenses connected with acceptance of administrative decisions and caused by consequences of these decisions.

At the second stage the following parameters of leasing programs are subject to estimation: term of leasing, size of a leasing payment (percent from cost of technics), conditions of delivery of object to the tenant, programs of consultations, start-up and adjustment of the equipment by the supplier or the leasing company, programs of training of personnel of the user of technics, maintenance with accompanying materials, maintenance of communications with business partners.

At the third operational stage it is important to evaluate leasing programs from the point of view of benefits received from features of warranty and post-warranty service maintenance of equipment, organization of repair, spare parts supply. It is also important to provide for the possibility of development and registration of relations on perspective use of the leasing object after the term of the leasing transaction is over. So the object can remain on the balance sheet of the leasing company, and the agricultural enterprise can get a new unit of equipment.

For each evaluation parameter of the algorithm it is necessary to select the method of evaluation. Selection of methods and their improvement is a precondition for effective choice of the leasing program. During estimation of parameters it is necessary to consider their importance for the user of technics. For example, if the agricultural enterprise has experienced specialists in operation and repair of machinery, it can consider itself less dependent on the leasing company, but if there are no such specialists, more reliable and effective service will be a weighty argument in favor of the choice of the leasing program.

The algorithm of the choice of the leasing program is directly built on the basis of the following table 12 , showing the main differences in the content of leasing programs.

The algorithm for choosing a leasing program for the purpose of making management decisions includes the following steps:

1. At the first stage the choice is made taking into account the leasing object. In crop production it can be movable and immovable property.

2. At the second stage the typicality of the acquired property is specified. Typical property or object under the individual project can be required.

3. At the third stage the duration of the transaction is specified

4. At the fourth stage the possibility to supplement the number of transaction objects is considered. 
5. At the fifth stage the necessary volume of service of leasing property is specified.

6. At the sixth stage the relation to depreciation privileges is specified.

7. At the final seventh stage the leasing interests are compared.

Table 12. Main differences of the content of leasing programs

\begin{tabular}{|c|c|c|}
\hline $\begin{array}{l}\text { Noo } \\
\text { p/p }\end{array}$ & Classification signs & Types of leasing \\
\hline \multirow{2}{*}{1} & \multirow{2}{*}{ Deal duration } & Operating lease \\
\hline & & Financial leasing \\
\hline \multirow{2}{*}{2} & \multirow{2}{*}{$\begin{array}{l}\text { Possibility to supplement the number of } \\
\text { transaction objects within the framework } \\
\text { of the agreement }\end{array}$} & General \\
\hline & & Standard \\
\hline \multirow{3}{*}{3} & \multirow{3}{*}{ Service volume of leasing property } & Net leasing \\
\hline & & Incomplete leasing services \\
\hline & & Full service leasing \\
\hline \multirow{2}{*}{4} & \multirow{2}{*}{ Amortization benefits ratio } & With evenly depreciation \\
\hline & & With accelerated depreciation \\
\hline \multirow{4}{*}{5} & \multirow{4}{*}{ Lease object } & Movable property leasing \\
\hline & & Property Leasing \\
\hline & & Seed Leasing \\
\hline & & Productive animal leasing \\
\hline \multirow{2}{*}{6} & \multirow{2}{*}{$\begin{array}{l}\text { Typicality of movable property as an } \\
\text { object of leasing }\end{array}$} & Leasing of standard movable property \\
\hline & & Leasing of special movable property \\
\hline \multirow{3}{*}{7} & \multirow{3}{*}{ Form of payment } & Money \\
\hline & & Mixed \\
\hline & & Compensatory \\
\hline
\end{tabular}

\section{Conclusions}

Thus, leasing can be referred to as a unique financial instrument. It simultaneously combines the properties of leasing, credit and financial investments to form new forms of business activity. All this contributes to the efficiency of the production system and provides renewal and formation of technical and technological potential of the industry, and this, in turn, leads to the development of the agro-industrial complex as a whole.

At the same time, issues of making managerial decisions on the use of leasing in agricultural production, based on traditional methods, do not provide the expected effect. In this regard, in the study we have proposed an algorithm for determining the variant of the form of capital investment financing, which is based on the choice of alternative options for the reproduction of the machine and tractor fleet. As one of the necessary tools for making managerial decisions it was suggested to use one of the methods of sociological method of the research - expert poll.

As a result of the conducted research for management purposes, we came to the conclusion that in order to make managerial decisions, representatives of enterprises need recommendations that help them choose the option of the form of investment financing. In case it is planned to dwell on such variant of the mechanism and instrument of financing as leasing, there is a need for explanations in terms of choosing a leasing program, studying the main differences in the content of leasing programs and defining the main stages of the algorithm of choosing a leasing program.

\section{References}

1. P. Rikhardsson, O. Yigitbasioglu. International Journal of Accounting Information Systems, 29, 37-58, (2018) doi.org/10.1016/j.accinf.2018.03.001 
2. G.S. Klychova, A.R. Zakirova, Z.R. Zakirov, G.R. Valieva. Asian Social Science, 1111, 308-312 (2015) DOI: 10.5539/ass.v11n11p308

3. O. Pavlatos, H. Kostakis. The Journal of Economic Asymmetries, 18, e00106 (2018) doi.org/10.1016/j.jeca.2018.e00106

4. D. Vakhitov, A. Zamaletdinov. Procedia Economics and Finance, 23, 839-845 (2015) doi.org/10.1016/S2212-5671(15)00365-2

5. X. Lu, Y. Li, Sh. Ke. Land Use Policy, 91, 104355 (2020) doi.org/10.1016/j.landusepol.2019.104355

6. A.A. Ajupov, O.E. Medvedeva and A.V. Sarkin. International Business Management, 10, 5752-5756 (2016) DOI: 10.36478/ibm.2016.5752.5756

7. P. José de Almeida, A. Márcio Buainain. Land Use Policy, 52, 206-220 (2016) doi.org/10.1016/j.landusepol.2015.12.028

8. J. Leontieva, G. Klychova, A. Zakirova. E. Zaugarova, A. Klychova. MATEC Web of Conferences, 170, 01087 (2018) https://doi.org/10.1051/matecconf/201817001087

9. G.S. Klychova, B.G. Ziganshin, A.R. Zakirova, G.R. Valieva, A.S. Klychova. Journal of Engineering and Applied Sciences, 12, 4958-4965 (2017) DOI: 10.3923/jeasci.2017.4958.4965

10. S. Kirchweger, J. Kantelhardt. Land Use Policy, 48, 73-93 (2015) doi.org/10.1016/j.landusepol.2015.05.005

11. S. Mandal, G. Vishwanath Misra, S. Mansoor Abbas Naqvi, N. Kumar. Land Use Policy, 88, 104106 (2019) doi.org/10.1016/j.landusepol.2019.104106

12. G. Klychova, A. Zakirova, R. Mannapova, K. Pinina and Y. Ryazanova. E3S Web of Conferences 110, 02075 (2019) doi.org/10.1051/e3sconf/201911002075

13. T. Afza, M. Jam-e-Kausar Ali Asghar. Procedia - Social and Behavioral Sciences, 109, 470-482 (2014) doi.org/10.1016/j.sbspro.2013.12.492

14. G. Klychova, Klychova, A. Zakirova, R. Sungatullina, K. Mukhamedzyanov and E. Philippova. E3S Web of Conferences, 110, $02072 \quad$ (2019) doi.org/10.1051/e3sconf/201911002072

15. L. G. Nabieva, L. M. Davletshina. Procedia Economics and Finance, 24, 457-463 (2015) doi.org/10.1016/S2212-5671(15)00703-0

16. L. Xin, X. Li. Land Use Policy, 86, 421-426 doi.org/10.1016/j.landusepol.2019.05.037

17. Y. Atnafe Yigezu, A. Mugera, T. El-Shater, A. Aw-Hassan, C. Piggin, A. Haddad, Y. Khalil, S. Loss. Technological Forecasting and Social Change, 134, 199-206 (2018) doi.org/10.1016/j.techfore.2018.06.006

18. D. C. Evison. Journal of Forest Economics, 33, 105-111 (2018) doi.org/10.1016/j.jfe.2018.06.001

19. G.S. Klychova, A.R. Zakirova, K.Z. Mukhamedzyanov, E.R. Sadrieva, A.S. Klychova. Journal of Engineering and Applied Sciences, 12 (19), 4966-4973 (2017) DOI: 10.3923/jeasci.2017.4966.4973

20. J. Ho Kim. Journal of Corporate Finance, 48, 375-412 (2018) doi.org/10.1016/j.jcorpfin.2017.11.010

21. P. Antonetti, M. Anesa. Journal of Business Research, 74, 1-10 (2017) doi.org/10.1016/j.jbusres.2016.12.011

22. J. K. Staniškis, E. Katiliūtè. Journal of Cleaner Production, 236, 117542 (2019) doi.org/10.1016/j.jclepro.2019.07.017 
23. G. Guimarães Nobre, F. Davenport, K. Bischiniotis, T. Veldkamp, B. Jongman, Ch. C. Funk, G. Husak, Ph. J. Ward, Jeroen C.J.H. Aerts. Science of The Total Environment, 653, 523-535 (2019) doi.org/10.1016/j.scitotenv.2018.10.406

24. M. Sultana, J. U. Ahmed, Y. Shiratake. Journal of Co-operative Organization and Management, 8, 100105 (2020) doi.org/10.1016/j.jcom.2019.100105

25. M. Tămăşilă, Ş. Miclea, M. Vartolomei, D. Pascu, C. Tiberiu Albulescu. Procedia Social and Behavioral Sciences, 238, 704-713 doi.org/10.1016/j.sbspro.2018.04.053

26. M. Effah Asamoah, I. Paul Alagidede. Research in International Business and Finance, 52, 101187 (2020) doi.org/10.1016/j.ribaf.2020.101187

27. G. Klychova, A. Zakirova, E. Sadrieva, F. Avkhadiev and A. Klychova. E3S Web of Conferences. 91. 06002 (2019) doi.org/10.1051/e3sconf/20199106002

28. H. Gao. Land Use PolicyVolume, 88, 104076 doi.org/10.1016/j.landusepol.2019.104076 